\title{
Rapid, sensitive, and specific immunomagnetic separation of foodborne pathogens
}

\author{
Emma B. Setterington \\ Department of Biosystems and Agricultural Engineering, \\ Michigan State University, \\ 115 Farrall Hall, East Lansing, \\ MI 48824-1323, USA \\ E-mail: ebs@msu.edu
}

\section{Barbara C. Cloutier}

Department of Large Animal Clinical Sciences,

Michigan State University,

115 Farrall Hall, East Lansing,

MI 48824-1323, USA

E-mail: cloutie5@cvm.msu.edu

\section{Jessica M. Ochoa}

Department of Homeland Security Minority Serving Institution, Summer Research Team,

115 Farrall Hall, East Lansing, MI 48824-1323, USA

E-mail: jochoa@poets.whittier.edu

\section{Ashley K. Cloutier}

115 Farrall Hall, East Lansing, MI 48824-1323, USA

E-mail: clouta@cuaa.edu

\author{
Parul J. Patel and Evangelyn C. Alocilja* \\ Department of Biosystems and Agricultural Engineering, \\ Michigan State University, \\ 115 Farrall Hall, East Lansing, \\ MI 48824-1323, USA \\ Fax: 517-432-2892 \\ E-mail: jainparu@msu.edu \\ E-mail: alocilja@msu.edu \\ *Corresponding author
}


Abstract: Food defence requires the means to efficiently screen large volumes of food for microbial pathogens. Even rapid detection methods often require lengthy enrichment steps, making them impractical for this application. There is a great need for rapid, sensitive, specific, and inexpensive methods for extracting and concentrating microbial pathogens from food. In this study, an immunomagnetic separation (IMS) methodology was developed for Escherichia coli O157:H7, using three different types of magnetic nanoparticles (MNPs). The microbiological specificity of the IMS method was evaluated against Escherichia coli $\mathrm{O} 55: \mathrm{H} 7$ and Shigella boydii, and was improved by addition of $\mathrm{NaCl}$ during conjugation of antibodies onto MNPs. The microbiological sensitivity of the IMS method was greatest when a high concentration of antibodies $(1.0 \mathrm{mg} / \mathrm{ml})$ was present during conjugation. MNP concentrations of $1.0 \mathrm{mg} / \mathrm{ml}$ and $0.5 \mathrm{mg} / \mathrm{ml}$ provided optimal sensitivity and specificity. The entire IMS procedure requires only 35 minutes, and antibody-conjugated MNPs show no decline in performance up to 60 days after conjugation.

Keywords: foodborne pathogens; E. coli $\mathrm{O} 157: \mathrm{H} 7$; E. coli $\mathrm{O} 55: \mathrm{H} 7$; Shigella boydii; immunomagnetic separation; IMS; magnetic nanoparticles; MNPs; iron oxide; polyaniline; core/shell nanoparticles; specificity; monoclonal antibody; food safety.

Reference to this paper should be made as follows: Setterington, E.B., Cloutier, B.C., Ochoa, J.M., Cloutier, A.K., Patel, P.J. and Alocilja, E.C. (2011) 'Rapid, sensitive, and specific immunomagnetic separation of foodborne pathogens', Int. J. Food Safety, Nutrition and Public Health, Vol. 4, No. 1, pp.83-100.

Biographical notes: Emma B. Setterington received her BS in Biosystems Engineering from the University of Arizona, Tucson, AZ, in 2008. She is currently completing her MS in Biosystems Engineering at Michigan State University, East Lansing, MI. Her research interests are in development of rapid diagnostics for infectious diseases.

Barbara C. Cloutier received her BS in Biochemistry from Alma College, Alma, MI, in 1992 and DVM from Michigan State University, in 1996. She has worked for ten years in private equine practice in Michigan and is currently a US Army Veterinary Corps, Major. Her current assignment is to complete her $\mathrm{PhD}$ in Food Defense at Michigan State University, East Lansing, MI through the College of Veterinary Medicine, Large Animal Clinical Sciences. Her research interests are bioterrorism and the development of rapid diagnostics for food defence programmes that mesh with industry and field ready needs.

Jessica M. Ochoa is currently pursuing her BA in Biology with a minor in Chemistry at Whittier College, Whittier, CA. She was part of the Department of Homeland Security Summer Research Team that conducted summer research at Michigan State University, East Lansing, MI. Her research interests are in immunology.

Ashley K. Cloutier is currently pursuing her BS in Biology with a minor in Chemistry at Concordia University, Ann Arbor, MI. She is interested in furthering her education with graduate studies in forensic biology at Michigan State University.

Parul J. Patel received her BS in Chemistry from Hindu College, University of Delhi, Delhi, India in 2002, MS in Chemistry from Indian Institute of Technology-Delhi, India in 2004, and $\mathrm{PhD}$ in Analytical Chemistry from 


\begin{abstract}
Michigan State University, East Lansing, MI in 2009. From 2004-2005, she worked as a Research Assistant at Indian Institute of Technology, Delhi, India. She is currently a Post-Doctoral Research Associate in the Department of Biosystems and Agricultural Engineering, Michigan State University. Her research interests are in protein purification, protein immobilisation and development of biosensors for rapid detection of microbial pathogens in food and water.

Evangelyn C. Alocilja received her BS in Chemistry from Silliman University, Philippines in 1973, MS in Soil Chemistry/Plant Physiology from the University of Philippines in 1981 and $\mathrm{MS}$ and $\mathrm{PhD}$ degrees in Systems Science/Electrical Engineering from Michigan State University, USA in 1983 and 1987, respectively. In addition to being an Associate Professor at Michigan State University, she is also an Adjunct Professor in the Institute of International Health at MSU and an Investigator of the National Center for Food Protection and Defense, a homeland security centre of excellence. Her research focus is on the development of nanoparticle-based biosensors for homeland security, food and water safety, and global health.
\end{abstract}

\title{
1 Introduction
}

Foodborne microbial pathogens comprise one of the single largest threats to maintaining a safe food supply. The realms of food defence (securing food sources against malicious biological attack) and food safety (identifying and eradicating contamination from natural sources) are growing increasingly relevant, as foods are processed and shipped further and faster than ever before. Standard overnight culture methods for identifying microbial pathogens are no longer adequate, as food defence demands rapid, sensitive, specific, and economical means of extracting and detecting pathogens from food sources. With this in view, the objective of this work was to develop an immunomagnetic separation (IMS) methodology for food borne pathogens that is both microbiologically sensitive and specific; that is, able to isolate target cells with high efficiency, and able to effectively discriminate against non-target cells.

IMS is a rapid method for extracting a target analyte from its sample matrix, and is an ideal starting point for any detection technique. IMS has been paired with a wide variety of biosensors for rapid detection of bacterial pathogens (Cheng et al., 2009; Gehring and Tu, 2005; Gehring et al., 1999; Jaffrezic-Renault et al., 2007; Maalouf et al., 2008; Perez et al., 1998; Ruan et al., 2002; Tu et al., 2005; Varshney and Li, 2007; Varshney et al., 2007, 2005; Yang and Li, 2006). In IMS, micro- or nanometre scale magnetic particles are immunofunctionalised with antibody, incubated with the sample to bind target cells, and separated from the sample matrix through application of a magnetic field. The magnetic particle-bound target can then be washed and concentrated in the testing medium. The possibility of concentrating target cells prior to detection can eliminate the need for time-consuming pre-enrichment steps. In comparison to centrifugation, filtration, or capture of target on an immunofunctionalised surface, the IMS method is simpler, and generally results in higher capture efficiency due to the greater surface area available for target binding.

Escherichia coli O157:H7, a type of enterohemorrhagic E. coli (EHEC), was chosen as the target strain for this study because it is a common and highly infective food- and 
water-borne pathogen. Symptoms of infection with $E$. coli $\mathrm{O} 157: \mathrm{H} 7$ include abdominal cramps, bloody diarrhea, nausea, vomiting, headache, and (in $2 \%$ to $-7 \%$ of cases) life-threatening hemolytic uremic syndrome (HUS), characterised by kidney failure and hemolytic anaemia (WHO, 2006). The pathogen is a fecal contaminant most often found in raw or undercooked meat, unwashed produce, unpasteurised milk, and fecal contaminated waters. The infectious dose of E. coli $0157: \mathrm{H} 7$ is 10 to 100 cells (FDA, 2009). Therefore, it is not acceptable for this pathogen to be present at any level in food or water intended for human use.

The US Center for Disease Control and Prevention (CDC) and the National Institute of Allergy and Infectious Diseases (NIAID) classify E. coli O157:H7 as a 'Category B' (second-highest priority) pathogen for biodefence, because of its ease of dissemination in water and food sources (CDC, 2010a; NIAID, 2009). Additionally, the CDC cites at least nine confirmed food-linked outbreaks of E. coli O157:H7 infection in the USA from 2006 to 2009 (CDC, 2010b), and estimates that 70,000 E. coli O157:H7 infections occur each year in the USA alone (CDC, 2008). This indicates a vital need for improved disease surveillance, diagnostic methodologies, prevention strategies, and food and water monitoring techniques.

The standard method of identifying E. coli $\mathrm{O} 157: \mathrm{H} 7$ from unknown samples is through enrichment in selective media, followed by growth on differential agar to isolate sorbitol non-fermenting colonies. These are identified phenotypically and serologically, and toxigenically characterised by PCR, a process lasting several days. For applications that require faster results and high throughput, E. coli O157:H7 can be identified (after selective enrichment) by real-time PCR, which provides a negative or positive result within 24 hours. But three days are still required to confirm presumptive positive results by culture methods and PCR. The standard method is able to detect $<1 \mathrm{CFU} / \mathrm{g}$ in foods (FDA, 2009).

The IMS method presented here could potentially be applied to extraction and concentration of $E$. coli $\mathrm{O} 157: \mathrm{H} 7$ from food samples, eliminating the standard method's overnight enrichment step. By pairing IMS with PCR or nearly any other rapid detection method, negative or presumptive positive results could be obtained in a few hours or less.

The development and application of electrically active magnetic nanoparticles (EAMNPs) for IMS has been previously reported by this laboratory (Pal et al., 2008; Pal and Alocilja, 2009). The reported method was effective in isolating target cells from pure culture and food matrices with reasonable sensitivity, but when challenged with non-target organisms, it demonstrated inadequate specificity.

The new IMS methodology reported in this work is able to isolate E. coli O157:H7 with excellent microbiological sensitivity, and specifically discriminate against $E$. coli O55:H7 and Shigella boydii. Additionally, this methodology requires a smaller volume of magnetic nanoparticles (MNPs) per extraction, and results in an MNP-antibody conjugate with a much longer storage life, as compared to our previous method. Both of these improvements contribute to a lower overall cost of the IMS assay.

Additionally, this IMS methodology was developed for three different types of MNPs: carboxylate-functionalised magnetic nanoparticles (CMNPs), amine-functionalised magnetic nanoparticles (AMNPs), and EAMNPs. The variety of particle types allows for flexibility in coupling chemistries, and enables the IMS methodology to be paired with a wider range of detection techniques. For example, the CMNPs and AMNPs consist of iron oxide particles with two unique surface chemistries that can covalently bind to antibodies or other proteins. The EAMNPs consist of an iron 
oxide core with a polyaniline coating which enables them to not only extract target cells, but also to function as the signal transducer in certain electrical detection platforms (Pal et al., 2008; Pal and Alocilja, 2009).

\section{Materials and methods}

\subsection{Reagents and equipment}

Ferric chloride hexahydrate (EMD chemicals), sodium acetate (CCI chemicals), sodium acrylate, sodium chloride $(\mathrm{NaCl})$, ethylene glycol, ethylenediamine, hydrochloric acid, aniline, iron (III) oxide nanopowder, ammonium persulfate, methanol, and diethyl ether were used as received in the synthesis of the MNPs. Nanoparticles were immunofunctionalised with monoclonal anti-E. coli O157:H7 antibodies obtained from Meridian Life Science, Inc. (Saco, ME). N-hydroxysuccinimide (NHS) and 1-ethyl-3-(3-dimethylaminopropyl) carbodiimide hydrochloride (EDC), both from Pierce/Thermo Scientific (Rockford, IL) were used in the coupling of antibodies onto MNPs.

Polysorbate-20 (Tween-20), Triton-X100, phosphate buffered saline (PBS), trizma base, casein, and sodium phosphate (dibasic and monobasic) were used in the IMS procedure. All of the above reagents, unless otherwise noted, were purchased from Sigma-Aldrich (St. Louis, MO).

All solutions and buffers used in this study were prepared in deionised (DI) water (from Millipore Direct-Q system) as follows: PBS buffer (10 mm PBS, pH 7.4), wash buffer (10 mm PBS, $\mathrm{pH} 7.4$, with $0.05 \%$ Tween- 20 or $0.05 \%$ Triton-X100), phosphate buffer (100 mm sodium phosphate, $\mathrm{pH}$ 7.4), blocking buffer (100 mm Tris- $\mathrm{HCl}$ buffer, $\mathrm{pH} 7.6$, with $0.01 \% \mathrm{w} / \mathrm{v}$ casein).

Magnetic separations were performed with a commercial magnetic separator (Promega Corporation, Madison, WI). Hybridisation of biological materials was carried out at room temperature with rotation on a tube rotisserie (Labquake, Thermo Scientific, MA). Scanning electron micrographs were acquired using field-emission scanning electron microscopy (SEM) (JOEL 7500F, acceleration voltage of $5 \mathrm{kV}$ ). A superconducting quantum interference device magnetometer (Quantum design MPMS SQUID) was used for magnetic characterisation of MNPs.

\subsection{Bacterial cell cultures}

E. coli $\mathrm{O} 157: \mathrm{H} 7$ (Sakai strain), E. coli O55:H7, and Shigella boydii were obtained from the Food Safety and Toxicology collection at Michigan State University. From frozen purified culture stocks (stored at $-70^{\circ} \mathrm{C}$ ), colonies were isolated by streak-plate method on trypticase soy agar (BD Biosciences, MD) plates. A single colony was used to inoculate a vial of tryptic soy broth (BD Biosciences, MD) and grown overnight at $37^{\circ} \mathrm{C}$. A portion of the liquid culture was transferred to a new vial of broth and stored at $37^{\circ} \mathrm{C}$ for up to six days. This culture was used to inoculate a new vial of broth 14 to $24 \mathrm{~h}$ before each experiment, to produce fresh bacterial cells which were serially diluted in $0.1 \%(\mathrm{w} / \mathrm{v})$ peptone water (Fluka-Biochemika, Switzerland) prior to their use in the IMS procedure. Viable cells were enumerated by microbial plating on MacConkey agar with 
sorbitol (BD Biosciences, $\mathrm{MD}$ ), according to standard rules for plate counting (FDA, 2009).

\subsection{Synthesis of MNPs}

The CMNPs were synthesised using a published solvothermal procedure (Xuan et al., 2009). Briefly, $\mathrm{FeCl}_{3} \cdot 6 \mathrm{H}_{2} \mathrm{O}$ (1.08 g), sodium acetate $(3.0 \mathrm{~g})$ and sodium acrylate $(3.0 \mathrm{~g})$ were dissolved in $40 \mathrm{~mL}$ of ethylene glycol for $2 \mathrm{~h}$ at room temperature. The yellow-coloured solution was transferred to a teflon-lined stainless-steel pressure vessel (container volume $125 \mathrm{~mL}$, Parr Instrument Company), sealed, and heated at $200^{\circ} \mathrm{C}$ for $15 \mathrm{~h}$. The pressure vessel was then cooled to room temperature and the synthesised nanoparticles were magnetically separated, washed with $20 \mathrm{~mL}$ of water three times and with $20 \mathrm{~mL}$ of ethanol three times, and dried overnight under vacuum. The resulting particles had an approximate average diameter of $180 \mathrm{~nm}$, and displayed a room temperature saturation magnetisation of $60 \mathrm{emu} / \mathrm{g}$.

The AMNPs were synthesised with slight modifications of a previously reported procedure (Barick et al., 2009). $\mathrm{FeCl}_{3} \cdot 6 \mathrm{H}_{2} \mathrm{O}(1.08 \mathrm{~g})$, sodium acetate $(2.0 \mathrm{~g})$ and ethylenediamine $(7.0 \mathrm{~mL})$ were dissolved in $30 \mathrm{~mL}$ of ethylene glycol for $2 \mathrm{~h}$ at room temperature. The solution was transferred to the teflon-lined stainless-steel pressure vessel (Parr Instrument Company), sealed, and heated at $200^{\circ} \mathrm{C}$ for $15 \mathrm{~h}$. The pressure vessel was then cooled to room temperature and the synthesised nanoparticles were magnetically separated, washed with $20 \mathrm{~mL}$ of water three times and with $20 \mathrm{~mL}$ of ethanol three times, and dried overnight under vacuum. The resulting particles had an approximate average diameter of 20 to $30 \mathrm{~nm}$, and displayed a room temperature saturation magnetisation of $80 \mathrm{emu} / \mathrm{g}$.

The polyaniline-coated magnetic nanoparticles (EAMNPs) were synthesised by polymerisation and acid doping of aniline monomer around gamma iron (III) oxide $\left(\gamma-\mathrm{Fe}_{2} \mathrm{O}_{3}\right)$ nanoparticles, using a slightly modified published procedure (Pal et al., 2008). Briefly, $0.650 \mathrm{~g}$ of iron (III) oxide nanopowder were dispersed in $50 \mathrm{~mL}$ of $1 \mathrm{M} \mathrm{HCl}$, $10 \mathrm{~mL}$ of DI water and $0.4 \mathrm{~mL}$ of aniline monomer by sonication in an ice bath for $1 \mathrm{~h}$. A volume of $20 \mathrm{~mL}$ of $0.2 \mathrm{M}$ ammonium persulfate (as oxidant) was added dropwise to the above solution under continuous magnetic stirring. Colour change from rust brown to dark green indicated formation of electrically-active (green) polyaniline over the smaller (brown) $\gamma-\mathrm{Fe}_{2} \mathrm{O}_{3}$ nanoparticles. The solution was stirred for $2 \mathrm{~h}$ in an ice bath and was filtered through a qualitative grade filter $(2.5 \mu \mathrm{m}$ pore size, Ahlstrom, grade 601). The supernatant thus obtained was successively filtered through a nitrocellulose membrane filter $(1.2 \mu \mathrm{m}$ pore size, Millipore) followed by washings with $10 \mathrm{~mL}$ each of $1 \mathrm{M} \mathrm{HCl}, 10 \%(\mathrm{v} / \mathrm{v})$ methanol, and diethyl ether. The particles weredried overnight at room temperature under vacuum. The particles ranged in size from 1.2 to $2.5 \mu \mathrm{m}$, and displayed a room temperature saturation magnetisation of $30 \mathrm{emu} / \mathrm{g}$.

\subsection{Conjugation of antibody onto MNPS}

Each type of MNP (AMNPs, CMNPs, and EAMNPs) was conjugated with monoclonal antibodies at an initial MNP concentration of $10 \mathrm{mg} / \mathrm{ml}$ ( $1 \%$ solids). Two different initial concentrations of monoclonal antibody were used during conjugation: $1.0 \mathrm{mg} / \mathrm{ml}$ antibody and $0.5 \mathrm{mg} / \mathrm{ml}$ antibody. Conjugation of antibodies onto MNPs was performed both with and without the addition of $\mathrm{NaCl}$. 
Conjugation of antibodies onto carboxylate- and AMNPs employed carbodiimide chemistry for covalent attachment of antibodies. First, $2.5 \mathrm{mg}$ of dry MNPs were suspended in $135 \mu \mathrm{l}$ of $0.1 \mathrm{M}$ phosphate buffer ( $\mathrm{pH} 7.4), 10 \mu \mathrm{l}$ of $0.1 \mathrm{M} \mathrm{NHS}$ and $5 \mu \mathrm{l}$ of $0.1 \mathrm{M} \mathrm{EDC}$, and dispersed by ultrasonication for $15 \mathrm{~min}$. A volume of $100 \mu \mathrm{l}$ of monoclonal anti-E. coli $\mathrm{O} 157: \mathrm{H} 7$ antibody (suspended in $0.1 \mathrm{M}$ phosphate buffer) was added, yielding a final antibody concentration of either $1.0 \mathrm{mg} / \mathrm{ml}$ or $0.5 \mathrm{mg} / \mathrm{ml}$. The mixture was hybridised on a rotisserie-style rotator for $1 \mathrm{~h}$ at room temperature, with $25 \mu l$ of 10 X PBS being added after the first 5 min of hybridisation, to increase the $\mathrm{NaCl}$ content of the suspension to approximately $0.14 \mathrm{M}$. (For select experiments, the $10 \mathrm{X}$ PBS was omitted). Following hybridisation, the MNP-antibody conjugate was magnetically separated, the supernatant removed, and the conjugate re-suspended in $250 \mu 1$ of blocking buffer $(0.1 \mathrm{M}$ tris buffer with $0.01 \%$ casein) for $5 \mathrm{~min}$. Again the conjugate was magnetically separated, the supernatant removed, and the conjugate re-suspended in $250 \mu \mathrm{l}$ of blocking buffer, this time for $1 \mathrm{~h}$ with rotation. Finally, the MNP-antibody conjugate was magnetically separated, the supernatant removed, and the conjugate re-suspended in $2.5 \mathrm{~mL}$ of $0.1 \mathrm{M}$ phosphate buffer.

Conjugation of antibodies onto EAMNPs was by direct physical adsorption and electrostatic interactions. The conjugation procedure was identical to that for CMNPs and AMNPs, except that no NHS or EDC was added.

The final concentration of MNPs in each solution was $1.0 \mathrm{mg} / \mathrm{ml}$. Immuno-conjugated MNPs (immuno-MNPs) were stored at $4^{\circ} \mathrm{C}$. Prior to experimental use, immuno-MNPs were either magnetically concentrated or further diluted in $0.1 \mathrm{M}$ phosphate buffer, in order to obtain solutions of each type of immuno-MNP (immuno-AMNPs, immuno-CMNPs, and immuno-EAMNPs) at the following concentrations: $1.5 \mathrm{mg} / \mathrm{ml}, 1.0 \mathrm{mg} / \mathrm{ml}, 0.5 \mathrm{mg} / \mathrm{ml}$, and $0.1 \mathrm{mg} / \mathrm{ml} \mathrm{MNPs}$.

\subsection{Experimental design}

This study was designed to test four distinct hypotheses, which were developed using the previously reported methodology (Pal et al., 2008; Pal and Alocilja, 2009) as a starting point, and with the goal of developing a new IMS methodology for E. coli O157:H7 that has both microbiological sensitivity and specificity.

It was hypothesised that the microbiological sensitivity and specificity of the IMS methodology is affected by:

1 the addition of $\mathrm{NaCl}$ to a concentration of about $0.14 \mathrm{M}$ during conjugation of antibodies onto MNPs

$(\mu$ salt $\neq \mu$ no salt; null hypothesis $\mu$ salt $=\mu$ no salt $)$

2 the concentration of antibodies present during conjugation of antibodies onto MNPs

$(\mu 1.0 \mathrm{mg} / \mathrm{ml} \neq \mu 0.5 \mathrm{mg} / \mathrm{ml} ;$ null hypothesis $\mu 1.0 \mathrm{mg} / \mathrm{ml}=\mu 0.5 \mathrm{mg} / \mathrm{ml})$

3 the concentration of immuno-MNPs present during IMS

$\left(\begin{array}{l}\mu 0.1 \mathrm{mg} / \mathrm{ml} \neq \mu 0.5 \mathrm{mg} / \mathrm{ml} \neq \mu 1.0 \mathrm{mg} / \mathrm{ml} \neq \mu 1.5 \mathrm{mg} / \mathrm{ml} ; \\ \text { null hypothesis } \mu 0.1 \mathrm{mg} / \mathrm{ml}=\mu 0.5 \mathrm{mg} / \mathrm{ml}=\mu 1.0 \mathrm{mg} / \mathrm{ml}=\mu 1.5 \mathrm{mg} / \mathrm{ml}\end{array}\right)$ 
4 the number of days elapsed since conjugation of antibodies onto MNPs

( $\mu$ day $0 \neq \mu$ day $\mathrm{x}$; null hypothesis $\mu$ day $0=\mu$ day $\mathrm{x}$ ).

In order to test the four hypotheses stated above, four factors ( $\mathrm{NaCl}$ addition, antibody concentration, immuno-MNP concentration, and age of the immuno-MNP solution) had to be evaluated in terms of their effect on the microbiological sensitivity and the microbiological specificity of the proposed IMS methodology. Therefore, every experiment was applied to three different bacterial species individually: E. coli O157:H7 (target species), E. coli $\mathrm{O} 55: \mathrm{H} 7$ and Shigella boydii (both non-target species). E. coli $\mathrm{O} 55: \mathrm{H} 7$ is another EHEC species, closely related to E. coli $\mathrm{O} 157: \mathrm{H} 7$. S. boydii bears less genotypic and phenotypic similarity to the target organism, but it is a commonly encountered foodborne pathogen, and also produces shiga-toxin like E. coli O157:H7. The non-target organisms chosen for this study correspond with the recommendations made by the AOAC Task Force on Best Practices in Microbiological Methodology (AOAC, 2006).

To test Hypothesis 1, immuno-MNPs made with the addition of $\mathrm{NaCl}$ were compared to those made without $\mathrm{NaCl}$. (In either case, the initial concentration of antibody was $1.0 \mathrm{mg} / \mathrm{ml}$.) Both with and without $\mathrm{NaCl}$, three concentrations $(1.0 \mathrm{mg} / \mathrm{ml}, 0.5 \mathrm{mg} / \mathrm{ml}$ and $0.1 \mathrm{mg} / \mathrm{ml}$ ) of each type of immuno-MNP were used to perform IMS.

To test Hypothesis 2, immuno-MNPs made with an initial antibody concentration of $1.0 \mathrm{mg} / \mathrm{ml}$ were compared to those made with an initial antibody concentration of $0.5 \mathrm{mg} / \mathrm{ml}$. (In either case, $\mathrm{NaCl}$ was added during conjugation). With both $1.0 \mathrm{mg} / \mathrm{ml}$ antibody and $0.5 \mathrm{mg} / \mathrm{ml}$ antibody, three concentrations $(1.0 \mathrm{mg} / \mathrm{ml}, 0.5 \mathrm{mg} / \mathrm{ml}$, and $0.1 \mathrm{mg} / \mathrm{ml}$ ) of each type of immuno-MNP were used to perform IMS.

To test Hypothesis 3, immuno-MNPs were made with the addition of $\mathrm{NaCl}$ and with an initial antibody concentration of $1.0 \mathrm{mg} / \mathrm{ml}$. Each of the four concentrations $(1.5 \mathrm{mg} / \mathrm{ml}, 1.0 \mathrm{mg} / \mathrm{ml}, 0.5 \mathrm{mg} / \mathrm{ml}$, and $0.1 \mathrm{mg} / \mathrm{ml})$ of each type of immuno-MNPs was used to perform IMS.

To test Hypothesis 4, immuno-MNPs were made with the addition of $\mathrm{NaCl}$, and with initial antibody concentrations of both $1.0 \mathrm{mg} / \mathrm{ml}$ and $0.5 \mathrm{mg} / \mathrm{ml}$. Two concentrations $(1.0 \mathrm{mg} / \mathrm{ml}$ and $0.5 \mathrm{mg} / \mathrm{ml})$ of each type of immuno-MNPs were used to perform IMS at various points from 0 to 60 days after conjugation.

\subsection{IMS and plating of bacteria}

Serial dilutions of each bacteria (E. coli $\mathrm{O} 157: \mathrm{H} 7$, E. coli $\mathrm{O} 55: \mathrm{H} 7$, and S. boydii) were independently prepared in $0.1 \%(\mathrm{w} / \mathrm{v})$ peptone water. Three or four of the pure dilutions of each bacteria were plated ( $100 \mu \mathrm{L}$ aliquots) on sorbitol MacConkey agar and incubated at $37^{\circ} \mathrm{C}$ overnight. For IMS, $50 \mu \mathrm{L}$ of immuno-MNPs and $50 \mu \mathrm{L}$ of the appropriate bacterial dilution were combined with $400 \mu \mathrm{L}$ of $0.01 \mathrm{M}$ PBS (pH 7.4), and hybridised with rotation at room temperature for $30 \mathrm{~min}$. After hybridisation, the cell-immuno-MNP complexes were magnetically separated and the supernatant removed. Complexes were washed twice in wash buffer $(0.01 \mathrm{M}$ PBS containing $0.05 \%$ Tween-20 or $0.05 \%$ Triton-X100), and finally re-suspended in $0.5 \mathrm{~mL}$ of $0.01 \mathrm{M}$ PBS. The IMS procedure required $35 \mathrm{~min}$, and is depicted in Figure 1. 
Figure 1 IMS procedure: sample plus immuno-MNPs $\rightarrow$ magnetic separation of target cells $\rightarrow$ removal of sample matrix $\rightarrow$ purified E. coli O157:H7-immuno-MNP complexes (see online version for colours)

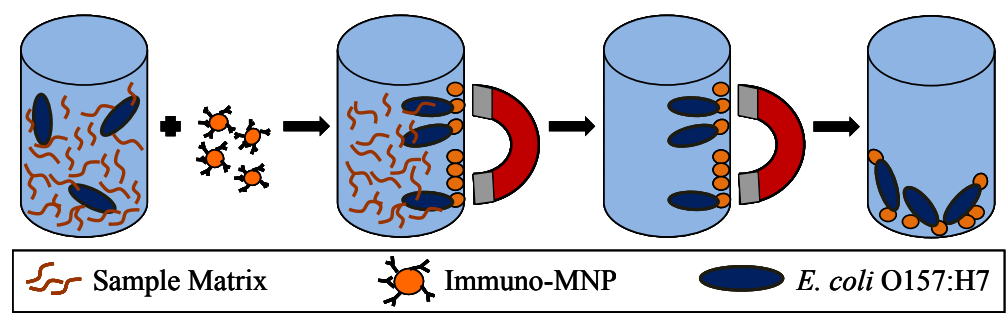

A $100 \mu \mathrm{L}$ portion was plated on sorbitol MacConkey agar and incubated at $37^{\circ} \mathrm{C}$ overnight. The number of colony-forming units (CFU) in the $100 \mu \mathrm{L}$ portion was determined by manually counting the colonies on each plate. For every experimental case (i.e., particular combination of immuno-MNP type, immuno-MNP concentration, and bacterial species), a minimum of two bacterial dilutions underwent IMS and were plated.

Calculation of bacterial cell concentrations in both pure and immunomagnetically separated samples were carried out according to rules provided by the US Food and Drug Administration's Bacteriological Analytical Manual (FDA, 2009). Plate counts between 25 and 250 colonies were used to calculate the original cell concentrations in CFU $/ \mathrm{mL}$. If all plate counts for a given case fell outside of this range, estimates were made according to FDA rules.

\subsection{Statistical analysis}

The calculated concentrations of cells captured by IMS (in CFU/mL) were converted to their $\log _{10}$ values for ease of analysis. Statistical analysis was performed using SPSS software. Missing values were computed with hot-deck imputation or excluded analysis by analysis. Independent, two-tailed t-tests were used to compare experiments in which $\mathrm{NaCl}$ was added during conjugation $(\mathrm{n}=140)$, to experiments in which $\mathrm{NaCl}$ was omitted $(n=45)$. In the same way, experiments in which the antibody concentration was $1.0 \mathrm{mg} / \mathrm{ml}(\mathrm{n}=168)$ were compared to experiments in which the antibody concentration was $0.5 \mathrm{mg} / \mathrm{ml}(\mathrm{n}=19)$. All experimental results were included for these two analyses.

Subsequent analysis was performed using both one-way ANOVA and independent two-tailed t-tests, to evaluate the effect of immuno-MNP concentration, for each type of MNPs. This analysis included only the results of experiments which had the $1.0 \mathrm{mg} / \mathrm{ml}$ antibody concentration and the addition of $\mathrm{NaCl}$ during conjugation (in the previous analyses, these parameters were statistically determined to result in better overall IMS performance). Analyses which showed abnormal data distributions were re-evaluated with Kruskal-Wallis or Mann-Whitney U tests as needed (for all MNPs at $0.1 \mathrm{mg} / \mathrm{ml}$, $\mathrm{n}=10 ; 0.5 \mathrm{mg} / \mathrm{ml}, \mathrm{n}=10 ; 1.0 \mathrm{mg} / \mathrm{ml}, \mathrm{n}=10 ; 1.5 \mathrm{mg} / \mathrm{ml}, \mathrm{n}=5)$.

Longevity of the immuno-MNP solutions was also evaluated by one-way ANOVA and independent two-tailed T-tests.

All analyses were calculated with $95 \%$ confidence intervals $(\alpha=0.05)$. 


\section{Results and discussion}

\subsection{Antibody conjugation and IMS}

Immuno-conjugation of the EAMNPs was carried out by physical adsorption of antibodies onto the polyaniline surface. Electrostatic interactions between the negatively charged constant $(\mathrm{Fc})$ portion of the antibodies and the positively charged polyaniline surface are thought to play a role in adsorption and orientation of the biomolecules onto the EAMNPs (Pal and Alocilja, 2009). Immuno-conjugation of the CMNPs and AMNPs is based on covalent attachment via carbodiimide chemistry. Successful conjugation of antibodies onto MNPs was confirmed by measuring the quantity of antibody in the post-hybridisation supernatant with a commercial fluorescence-based protein quantification kit. The measured protein concentration in the supernatant was significantly lower than the concentration of antibodies initially added to the MNPs (data not shown), indicating that antibodies were retained on the MNPs during hybridisation.

Figure 2 Scanning electron micrograph of (a) an individual EAMNP with diameter of approximately $1.3 \mu \mathrm{m}$ and (b) an immuno-EAMNP bound to an $E$. coli $\mathrm{O} 157: \mathrm{H} 7$ cell

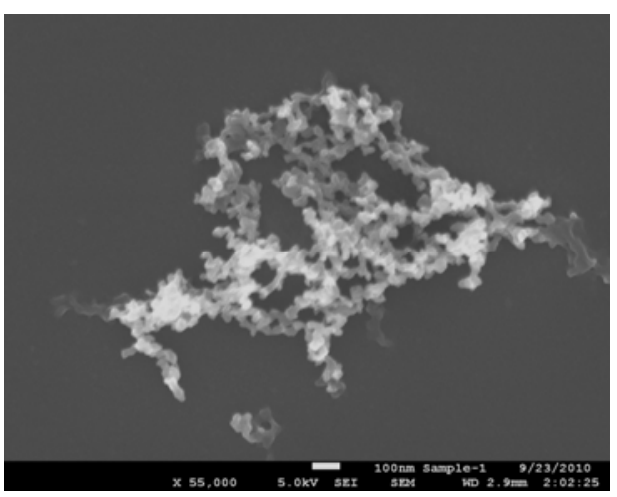

(a)

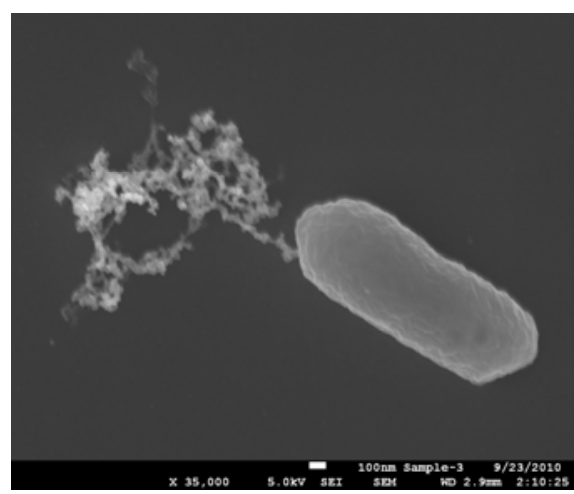

(b)

Immunomagnetic capture of $E$. coli $\mathrm{O} 157: \mathrm{H} 7$ cells was quantified by plate counts, but capture was also visually confirmed by SEM. Figure 2 shows SEM images of

a an individual EAMNP with diameter of approximately $1.3 \mu \mathrm{m}$

b an immuno-EAMNP bound to an $E$. coli $\mathrm{O} 157: \mathrm{H} 7$ cell, after washing twice to remove non-specifically bound cells.

\subsection{Hypothesis 1: effect of $\mathrm{NaCl}$ addition during conjugation}

Conjugation of antibodies onto MNPs was carried out in phosphate buffer at pH 7.4. A slightly basic $\mathrm{pH}$ such as this is recommended for optimal adsorption of the $\mathrm{Fc}$ (constant) portion of the antibody (Bangs Laboratories, 2008a), which positions the Fab (antigen-binding) portion outward for maximum target-binding capacity.

Also, it has been reported that the addition of $\mathrm{NaCl}$ at or near physiological concentration (about $0.15 \mathrm{M}$ ) increases adsorption efficiency of antibodies onto microspheres (Bangs Laboratories, 2008b). This was the foundation for Hypothesis 1, 
that the addition of $\mathrm{NaCl}$ during conjugation will affect the microbiological sensitivity and specificity of IMS.

Two-tailed independent T-tests performed on the mean concentrations of captured cells $\left(\log _{10}\right.$ of $\left.\mathrm{CFU} / \mathrm{mL}\right)$ for all three bacteria showed that the addition of $\mathrm{NaCl}$ (compared with omitting $\mathrm{NaCl}$ ) causes a significant decrease in capture of the negative control S. boydii $(\mathrm{p}=0.029 ; \mathrm{CI}=0.05,1.04)$, with no significant effect on the capture of the target $E$. coli $\mathrm{O} 157: \mathrm{H} 7$ or the other negative control E. coli $\mathrm{O} 55: \mathrm{H} 7$.

When separated according to MNP type, CMNPs showed the most significant decrease $(\mathrm{p}=0.047, \mathrm{CI}=0.01,2.07)$ in capture of $S$. boydii with addition of $\mathrm{NaCl}$. This remained true when the data was separated according to MNP type and immuno-MNP concentration. At the $0.1 \mathrm{mg} / \mathrm{ml}$ MNP concentration, both AMNPs and CMNPs showed a significant increase in capture of negative control E. coli $\mathrm{O} 55: \mathrm{H} 7(\mathrm{p}=0.021, \mathrm{CI}=-1.83$, -0.18 , and $\mathrm{p}=0.044, \mathrm{CI}=-2.62,-0.038$, respectively).

Based on these statistical results, Null Hypothesis 1 is rejected. The addition of $0.14 \mathrm{M} \mathrm{NaCl}$ during conjugation of antibodies onto MNPs increases the specificity of all three MNPs at all immuno-MNP concentrations evaluated, and has no effect on sensitivity (Figure 3). Addition of $\mathrm{NaCl}$ during conjugation is a simple and inexpensive procedural change able to enhance IMS performance for any application.

Figure 3 Mean concentration $(\log 10$ of $\mathrm{CFU} / \mathrm{ml})$ of each bacterial culture captured in IMS, using immuno-MNPs made with and without the addition of $\mathrm{NaCL}$

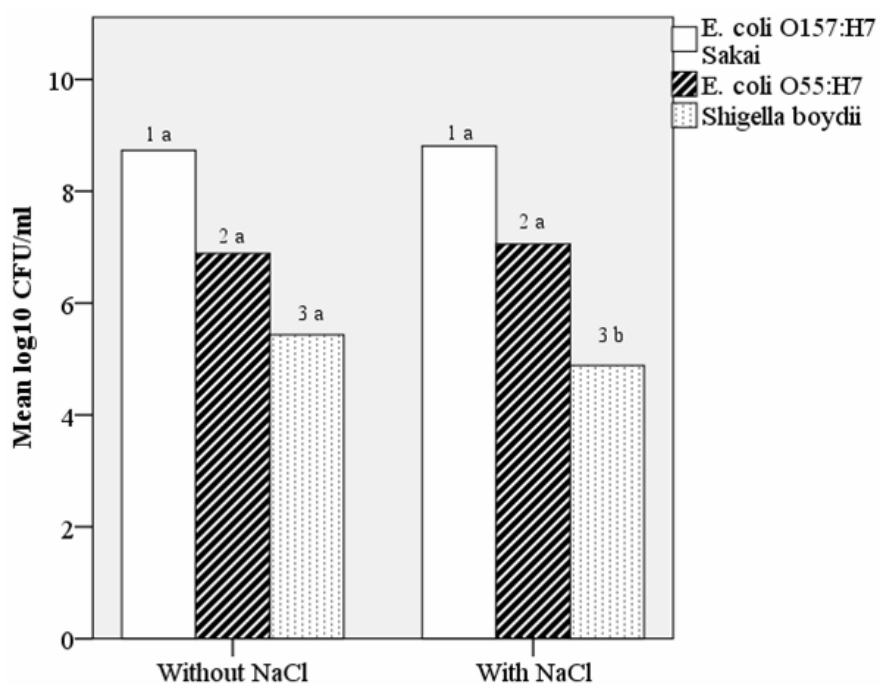

Notes: Results from each type of immuno-MNP are included. Statistical comparisons were made within numbered groups (1-3), and letters (a or b) indicate significant differences $(\alpha=0.05)$.

\subsection{Hypothesis 2: effect of antibody concentration during conjugation}

During conjugation of antibodies onto MNPs, MNPs were present at a concentration of $10 \mathrm{mg} / \mathrm{ml}$, or $1 \%$ solids. The solution volume was kept small $(250 \mu \mathrm{L}$, until post-conjugation dilution) in order to increase the speed and frequency of interactions between antibodies and MNPs during conjugation. Monoclonal antibody was added at 
relatively high concentrations of $1.0 \mathrm{mg} / \mathrm{ml}$ or $0.5 \mathrm{mg} / \mathrm{ml}$ during conjugation, since the presence of excess antibody is thought to contribute to the correct orientation of adsorbed antibodies (Bangs Laboratories, 2008a, 2008b). This was the foundation for Hypothesis 2, that the concentration of antibodies present during conjugation of will affect the microbiological sensitivity and specificity of IMS.

Two-tailed independent t-tests performed on the mean concentrations of captured cells $\left(\log _{10}\right.$ of $\left.\mathrm{CFU} / \mathrm{mL}\right)$ for all three bacteria showed that the higher antibody concentration $(1.0 \mathrm{mg} / \mathrm{ml})$ caused a significant increase in capture of the target $E$. coli $\mathrm{O} 157: \mathrm{H} 7(\mathrm{p}=0.018 ; \mathrm{CI}=-2.08,-0.23)$, with no significant effect on the capture of the negative control microorganisms.

When separated according to MNP type, CMNPs showed the most significant increase $(\mathrm{p}=0.000, \mathrm{CI}=-2.05,-0.75)$ in capture of $E$. coli $\mathrm{O} 157: \mathrm{H} 7$ with the higher antibody concentration. When separated according to both MNP type and immuno-MNP concentration, the number of data points per case was insufficient to draw conclusions on specificity.

Based on these statistical results, Null Hypothesis 2 is rejected. The higher antibody concentration $(1.0 \mathrm{mg} / \mathrm{ml})$ during conjugation increases the sensitivity of all three MNPs at all immuno-MNP concentrations evaluated, and has no effect on specificity (Figure 4). Although consumption of more antibodies increases the cost of the assay, it is worthwhile for some IMS applications. Since the infectious dose of E. coli O157:H7 is only 10 to 100 cells (FDA, 2009), high sensitivity is a critical feature in any IMS assay for this organism. However if IMS is being applied to a pathogen like Bacillus cereus, with an infectious dose greater than $10^{6}$ cells (FDA, 2009), then decreasing the cost of the assay would likely be of greater value than increasing the sensitivity, and a lower antibody concentration may be ideal.

Figure 4 Mean concentration ( $\log 10$ of CFU/ml) of each bacterial culture captured in IMS, using immuno-MNPs made with $1.0 \mathrm{mg} / \mathrm{ml}$ antibody and with $0.5 \mathrm{mg} / \mathrm{ml}$ antibody

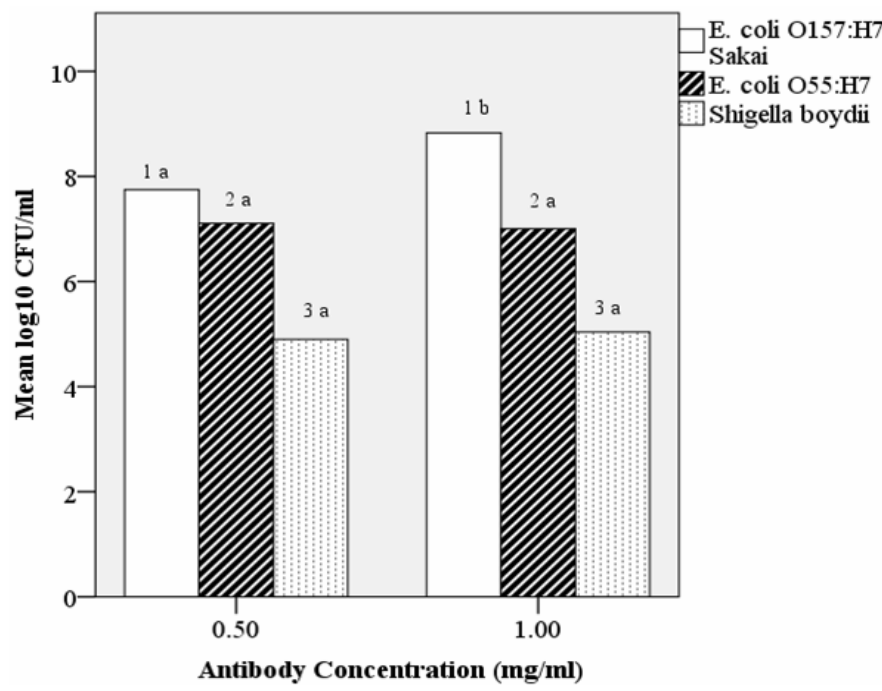

Notes: Results from each type of immuno-MNP are included. Statistical comparisons were made within numbered groups (1-3), and letters (a or b) indicate significant differences $(\alpha=0.05)$. 


\subsection{Hypothesis 3: effect of immuno-MNP concentration during IMS}

With the objective of developing an IMS methodology that is microbiologically sensitive and specific, but also practical and cost-effective, the concentration of immuno-MNPs employed in IMS was identified as an important parameter to be optimised. This concern led to Hypothesis 3, that the concentration of immuno-MNPs present during IMS will affect the microbiological sensitivity and specificity of IMS.

One-way ANOVA was performed on the mean concentrations of captured cells $\left(\log _{10}\right.$ of $\left.\mathrm{CFU} / \mathrm{mL}\right)$ for all three bacteria, separated according to MNP type and immuno-MNP concentration, using only the results of experiments which had the $1.0 \mathrm{mg} / \mathrm{ml}$ antibody concentration and the addition of $\mathrm{NaCl}$ during conjugation. No significant difference in the capture of the target $E$. coli $\mathrm{O} 157: \mathrm{H} 7$ was observed at any immuno-MNP concentration with this test (LDS and Bonferroni pairwise comparison). The only exception to this is that AMNPs at $1.0 \mathrm{mg} / \mathrm{ml}$ captured significantly more E. coli $\mathrm{O} 157: \mathrm{H} 7$ than AMNPs at $0.5 \mathrm{mg} / \mathrm{ml}$ (t-test, $\mathrm{p}=0$.047). However, the ANOVA homogeneity of variance test showed non-normal distributions for various MNP types and various bacteria. To account for the non-normality observed in the ANOVA, independent T-tests were also performed for each MNP type and for all three bacteria, and these did show some significant differences in medians, with the non-parametric comparison (using the Kruskal-Wallis test for median and distribution, or the Mann-Whitney two-sample comparison). From these statistical analyses, the following conclusions were drawn:

- CMNPs at both $1.5 \mathrm{mg} / \mathrm{ml}$ and $0.1 \mathrm{mg} / \mathrm{ml}$ are less specific than CMNPs at either $1.0 \mathrm{mg} / \mathrm{ml}$ or $0.5 \mathrm{mg} / \mathrm{ml}$. Concentration of CMNPs has no effect on sensitivity. There is no significant difference between CMNPs at $1.0 \mathrm{mg} / \mathrm{ml}$ and at $0.5 \mathrm{mg} / \mathrm{ml}$, regarding either sensitivity or specificity.

- AMNPs at $0.1 \mathrm{mg} / \mathrm{ml}$ are less specific than any other concentration of AMNPs. AMNPs at $1.0 \mathrm{mg} / \mathrm{ml}$ are more sensitive than AMNPs at $0.5 \mathrm{mg} / \mathrm{ml}$. There are no other significant differences between any of the AMNP concentrations, regarding either sensitivity or specificity.

- EAMNPs at both $1.5 \mathrm{mg} / \mathrm{ml}$ and $0.1 \mathrm{mg} / \mathrm{ml}$ are less specific than EAMNPs at either $1.0 \mathrm{mg} / \mathrm{ml}$ or $0.5 \mathrm{mg} / \mathrm{ml}$. Despite the small number of data points $(\mathrm{n}=5)$ for EAMNPs at $1.5 \mathrm{mg} / \mathrm{ml}$, this concentration is more sensitive than any other concentration of EAMNPs.

Based on these statistical results, Null Hypothesis 3 is rejected. The concentration of immuno-MNPs present during IMS has an effect on both sensitivity and specificity, for each type of immuno-MNPs (Figure 5). In most cases where the immuno-MNP concentration had a significant effect on bacterial capture, concentrations of $1.0 \mathrm{mg} / \mathrm{ml}$ and $0.5 \mathrm{mg} / \mathrm{ml}$ provide the optimal microbiological sensitivity and specificity. These findings offer the experimenter some flexibility in tailoring the IMS methodology to suit a particular application, depending on whether sensitivity or specificity is of greater concern. Also, a very low immuno-MNP concentration (such as $0.1 \mathrm{mg} / \mathrm{ml}$ ) could be employed to drastically decrease the cost of the assay in cases where neither sensitivity nor specificity must be optimal (for example, high-throughput yes/no screening of food products, with tolerance levels greater than zero). 
Figure 5 Mean concentration $\left(\log _{10}\right.$ of $\left.\mathrm{CFU} / \mathrm{ml}\right)$ of each bacterial culture captured in IMS, using (a) immuno-CMNPs, (b) immuno-AMNPs, and (c) immuno-EAMNPs at concentrations of $1.5 \mathrm{mg} / \mathrm{ml}, 1.0 \mathrm{mg} / \mathrm{ml}, 0.5 \mathrm{mg} / \mathrm{ml}$, and $0.1 \mathrm{mg} / \mathrm{ml}$

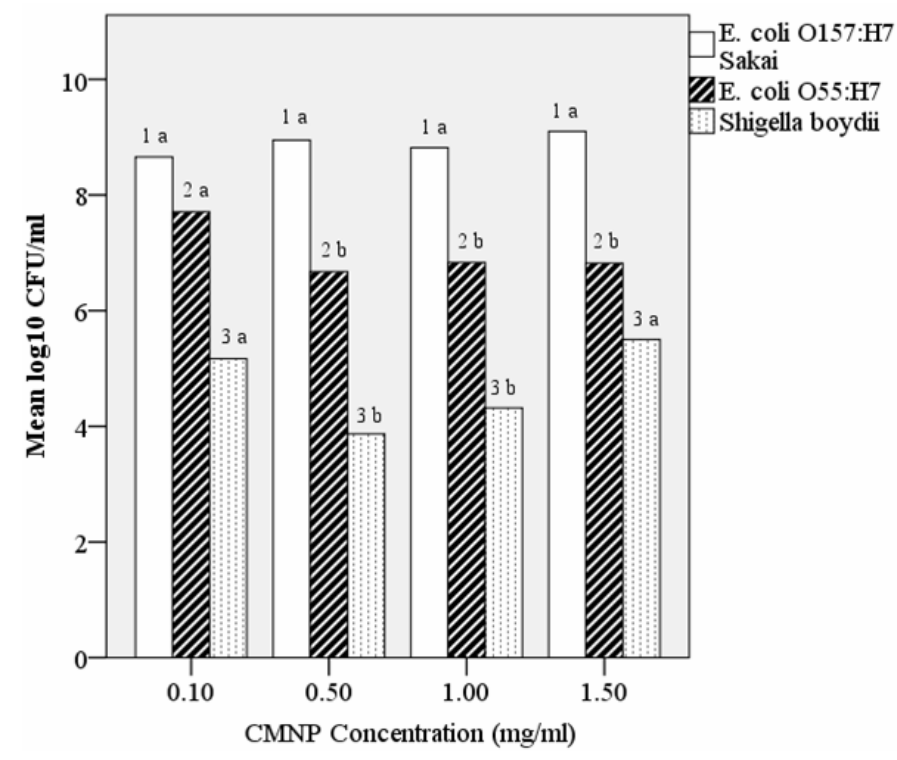

(a)

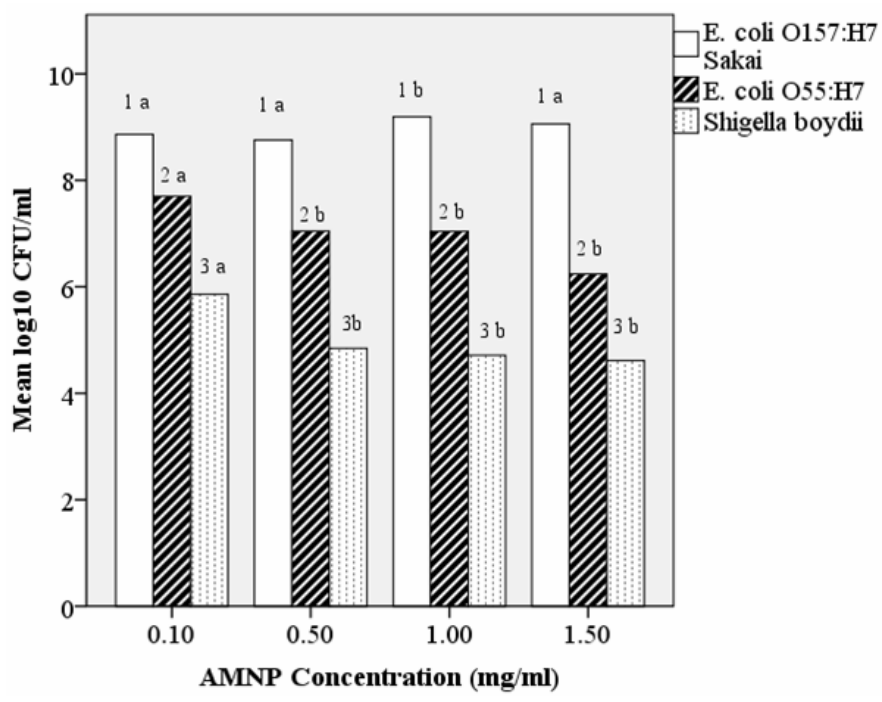

(b)

Notes: Statistical comparisons were made within numbered groups (1-3), and letters (a or b) indicate significant differences $(\alpha=0.05)$. 
Figure 5 Mean concentration $\left(\log _{10}\right.$ of $\left.\mathrm{CFU} / \mathrm{ml}\right)$ of each bacterial culture captured in IMS, using (a) immuno-CMNPs, (b) immuno-AMNPs, and (c) immuno-EAMNPs at concentrations of $1.5 \mathrm{mg} / \mathrm{ml}, 1.0 \mathrm{mg} / \mathrm{ml}, 0.5 \mathrm{mg} / \mathrm{ml}$, and $0.1 \mathrm{mg} / \mathrm{ml}$ (continued)

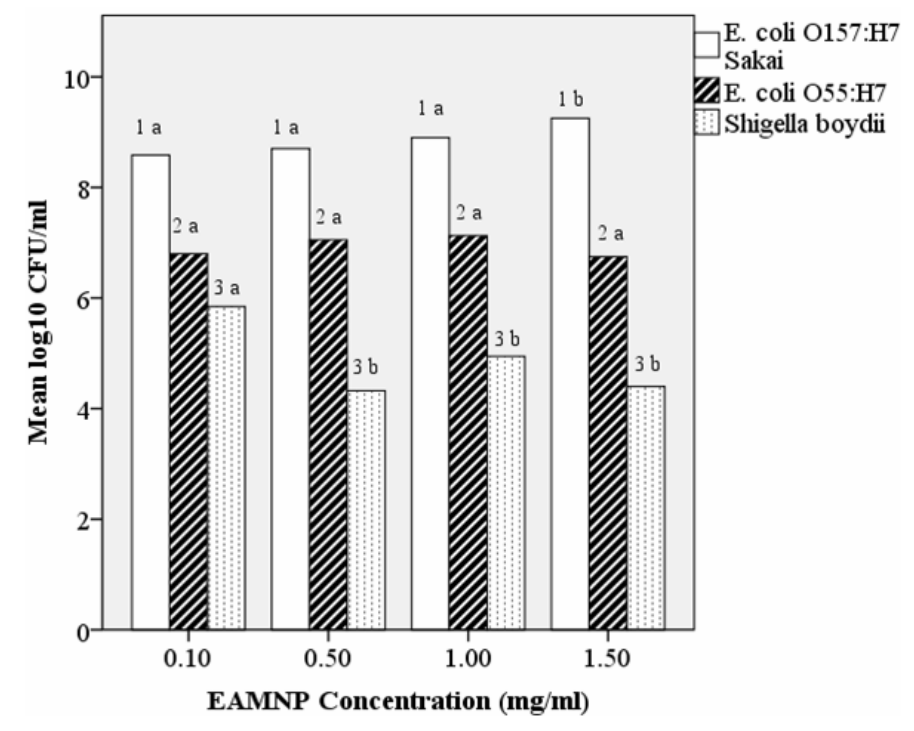

(c)

Notes: Statistical comparisons were made within numbered groups (1-3), and letters (a or b) indicate significant differences $(\alpha=0.05)$.

\subsection{Hypothesis 4: effect of age of immuno-MNP solution during IMS}

With the previously reported method of conjugating antibodies onto MNPs (Pal et al., 2008, Pal and Alocilja, 2009), long term storage of immuno-MNP solutions (at $4^{\circ} \mathrm{C}$ ) resulted in poorer IMS performance. This observation led to Hypothesis 4, that the number of days elapsed since conjugation of antibodies onto MNPs will affect the microbiological sensitivity and specificity of IMS.

One-way ANOVA and independent two-tailed T-tests were performed on the mean concentration of captured cells $\left(\log _{10}\right.$ of $\left.\mathrm{CFU} / \mathrm{mL}\right)$ for all three bacteria, comparing the experimental results obtained from immuno-MNP solutions ranging in age from 0 days to 60 days. Regardless of which statistical test was applied, no significant difference was observed in IMS capture of any of the three bacteria.

Based on these statistical results, Null Hypothesis 4 is retained. Days elapsed since conjugation of antibodies onto MNPs (stored at $4^{\circ} \mathrm{C}$ ), from 0 to 60 days, has no effect on sensitivity or specificity. The excellent longevity of the immuno-MNPs makes the proposed IMS methodology more practical and cost-effective, by reducing both the labour and the materials required.

This study has laid the foundation for application of the IMS method to food samples. Future research will focus on quantifying the sensitivity (in terms of $\mathrm{LOD}_{50}$ and false negatives), specificity (in terms of false positives), and ability of the IMS system to concentrate target bacterial cells from food matrices. Additionally, the IMS methodology will be applied to various biosensor platforms for rapid detection of foodborne pathogens. 


\section{Conclusions}

The experiments designed and executed in this study provided conclusive results, allowing the initial hypotheses to be either rejected or retained. The microbiological specificity of the IMS method was improved by adding $0.14 \mathrm{M} \mathrm{NaCl}$ during conjugation of antibodies onto MNPs. The microbiological sensitivity of the IMS method was improved by using a high initial concentration of monoclonal antibodies $(1.0 \mathrm{mg} / \mathrm{ml})$ during conjugation. In most cases where immuno-MNP concentration was significant, concentrations of $1.0 \mathrm{mg} / \mathrm{ml}$ and $0.5 \mathrm{mg} / \mathrm{ml}$ provided the optimal microbiological sensitivity and specificity. The immuno-MNPs were proven to have excellent longevity, with no decline in performance up to 60 days after conjugation.

The IMS methodology presented here is sensitive, specific, rapid, and inexpensive. The entire IMS procedure requires only $35 \mathrm{~min}$. It shows potential for extraction and concentration of microbial pathogens from food matrices, eliminating overnight enrichment steps, and could be paired with nearly any rapid detection method for practical applications in food defence, food and water safety, and clinical diagnostics.

\section{Acknowledgements}

This work was funded in part by the US Department of Homeland Security through the National Center for Food Protection and Defense under Grant R9106007101, and in part by the US Environmental Protection Agency through award number RD83300501. These funding sources had no involvement in the actual research or writing of this report. The contents of this publication do not necessarily reflect the position or policy of the Federal Government.

The authors would like to thank Dr. Stanley Flegler and Carol Flegler for assistance with SEM studies, Dr. Reza Loloee for assistance with magnetism measurements, Dr. Paul Bartlett and the MSU Center for Statistical Training and Consulting (CSTAT) for assistance with statistical analyses, Dr. Julie Funk and Dr. Shannon Manning for providing bacterial cultures and for advice on microbiological methods, and Dr. John Linz and Dr. Elliot Ryser for offering information on best practices in food microbiology.

\section{References}

AOAC (2006) Final report and executive summaries from the AOAC international presidential task force on best practices in microbiological methodology, AOAC International.

Bangs Laboratories, I. (2008a) TechNote 201: Working with Microspheres.

Bangs Laboratories, I. (2008b) TechNote 204: Adsorption to Microspheres.

Barick, K.C., Aslam, M., Prasad, P.V., Dravid, V.P. and Bahadur, D. (2009) 'Nanoscale assembly of amine-functionalized colloidal iron oxide', Journal of Magnetism and Magnetic Materials, Vol. 321, No. 10, pp.1529-1532.

CDC (2008) Escherichia coli, Centers for Disease Control and Prevention, available at http://www.cdc.gov/nczved/dfbmd/disease listing/stec_gi.html (accessed on 7 October 2010). 
CDC (2010a) Bioterrorism Agents/Diseases, Center for Disease Control and Prevention, Atlanta, GA, available at http://www.bt.cdc.gov/agent/agentlist-category.asp (accessed on 7 October 2010).

CDC (2010b) E. coli Outbreak Investigations, Center for Disease Control and Prevention, Atlanta, GA, available at http://www.cdc.gov/ecoli/outbreaks.html (accessed on 12 October 2010).

Cheng, Y., Liu, Y., Huang, J., Li, K., Zhang, W., Xian, Y. and Jin, L. (2009) 'Combining biofunctional magnetic nanoparticles and ATP bioluminescence for rapid detection of Escherichia coli', Talanta, Vol. 77, No. 4, pp.1332-1336.

FDA (2009) Bacteriological Analytical Manual (BAM), US Food \& Drug Administration.

Gehring, A.G., Brewster, J.D., Irwin, P.L., Tu, S-I. and Van Houten, L.J. (1999) '1-Naphthyl phosphate as an enzymatic substrate for enzyme-linked immunomagnetic electrochemistry', Journal of Electroanalytical Chemistry, Vol. 469, No. 1, pp.27-33.

Gehring, A.G. and Tu, S-I. (2005) 'Enzyme-linked immunomagnetic electrochemical detection of live Escherichia coli O157:H7 in apple juice', Journal of Food Protection, Vol. 68, No. 1, pp.146-149.

Jaffrezic-Renault, N., Martelet, C., Chevolot, Y. and Cloarec, J-P. (2007) 'Biosensors and bio-bar code assays based on biofunctionalized magnetic microbeads', Sensors, Vol. 7, No. 4, pp.589-614.

Maalouf, R., Hassen, W., Fournier-Wirth, C., Coste, J. and Jaffrezic-Renault, N. (2008) 'Comparison of two innovatives approaches for bacterial detection: paramagnetic nanoparticles and self-assembled multilayer processes', Microchimica Acta, Vol. 163, Nos. 3-4, pp.157-161.

NIAID (2009) Biodefense: NIAID Category A, B, and C Priority Pathogens, National Institute of Allergy and Infectious Diseases, available at http//:www3.niaid.nih.gov/topics/ BiodefenseRelated/Biodefense/research/CatA.htm (accessed on 7 October 2010).

Pal, S. and Alocilja, E.C. (2009) 'Electrically active polyaniline coated magnetic (EAPM) nanoparticle as novel transducer in biosensor for detection of Bacillus anthracis spores in food samples', Biosens Bioelectron, Vol. 24, No. 5, pp.1437-1444.

Pal, S., Setterington, E.B. and Alocilja, E.C. (2008) 'Electrically active magnetic nanoparticles for concentrating and detecting bacillus anthracis spores in a direct-charge transfer biosensor', Sensors Journal, IEEE, Vol. 8, No. 6, pp.647-654.

Perez, F.G., Mascini, M., Tothill, I.E. and Turner, A.P.F. (1998) 'Immunomagnetic separation with mediated flow injection analysis amperometric detection of viable Escherichia coli O157', Analytical Chemistry, Vol. 70, No. 11, pp.2380-2386.

Ruan, C., Wang, H. and Li, Y. (2002) 'A bienzyme electrochemical biosensor coupled with immunomagnetic separation for rapid detection of Escherichia coli O157:H7 in food samples', Transactions of the ASAE, Vol. 45, pp.249-255.

Tu, S-I., Golden, M., Cooke, P., Paoli, G. and Gehring, A. (2005) 'Detection of Escherichia coli O157:H7 through the formation of sandwiched complexes with immunomagnetic and fluorescent beads', Journal of Rapid Methods \& Automation in Microbiology, Vol. 13, No. 4, pp.269-282.

Varshney, M. and Li, Y. (2007) 'Interdigitated array microelectrode based impedance biosensor coupled with magnetic nanoparticle-antibody conjugates for detection of Escherichia coli O157:H7 in food samples', Biosens Bioelectron, Vol. 22, No. 11, pp.2408-2414.

Varshney, M., Li, Y., Srinivasan, B. and Tung, S. (2007) 'A label-free, microfluidics and interdigitated array microelectrode-based impedance biosensor in combination with nanoparticles immunoseparation for detection of Escherichia coli O157:H7 in food samples', Sensors and Actuators B: Chemical, Vol. 128, No. 1, pp.99-107. 
Varshney, M., Yang, L., Su, X.L. and Li, Y. (2005) 'Magnetic nanoparticle-antibody conjugates for the separation of Escherichia coli O157:H7 in ground beef', J Food Prot, Vol. 68, No. 9, pp.1804-1811.

WHO (2006) Guidelines for Drinking-Water Quality, 3rd ed., World Health Organisation, available at http://www.who.int/water_sanitation_health/dwq/gdwq3rev/en/index.html (accessed on 24 July 2010).

Xuan, S., Wang, Y-X.J., Yu, J.C. and Leung, K.C-F. (2009) 'Preparation, characterization, and catalytic activity of core/shell Fe3O4@Polyaniline@Au nanocomposites', Langmuir, Vol. 25, No. 19, pp.11835-11843.

Yang, L. and Li, Y. (2006) 'Detection of viable salmonella using microelectrode-based capacitance measurement coupled with immunomagnetic separation', Journal of Microbiological Methods, Vol. 64, No. 1, pp.9-16. 